\title{
Combination OX40 agonism/CTLA-4 blockade with HER2 vaccination reverses T cell anergy and promotes survival in tumor-bearing mice
}

\author{
Stefanie Linch ${ }^{1}$, Melissa J Kasiewicz ${ }^{2 *}$, Michael McNamara², lan Hilgart-Martiszus ${ }^{2}$, Mohammad Farhad $^{2}$, \\ William Redmond ${ }^{2}$
}

From 30th Annual Meeting and Associated Programs of the Society for Immunotherapy of Cancer (SITC 2015) National Harbor, MD, USA. 4-8 November 2015

Immunotherapy is gathering momentum as a primary therapy for cancer patients. However, monotherapies have limited efficacy in improving outcomes and only benefit a subset of patients. Combination therapies targeting multiple pathways can augment an immune response to further improve survival. Here, we demonstrate that dual anti-OX40/anti-CTLA-4 immunotherapy generated a potent antigen-specific CD8 $\mathrm{T}$ cell response, enhancing expansion, effector function, and memory $\mathrm{T}$ cell persistence. Importantly, OX40 and CTLA-4 expression on CD8 $\mathrm{T}$ cells was critical to maximally promote their expansion following combination therapy. Animals treated with combination therapy and vaccination using anti-DEC-205-HER2 had significantly improved survival in a mammary carcinoma model. Vaccination with combination therapy uniquely restricted Th2-cytokine production by CD4 cells, relative to combination therapy alone, and enhanced IFN $\alpha$ production by CD8 and CD4 cells. We observed an increase in MIP-1 $\alpha /$ CCL3, MIP$1 \beta / C C L 4$, RANTES/CCL5, and GM-CSF production by CD8 and CD4 T cells following treatment. Furthermore, this therapy was associated with extensive tumor destruction and $\mathrm{T}$ cell infiltration into the tumor. Notably, vaccination with combination therapy reversed anergy and enhanced the expansion and function of CD8 T cells recognizing a tumor-associated antigen in a spontaneous model of prostate adenocarcinoma. Collectively, these data demonstrate that the addition of an anti-DEC-205-HER2 vaccine with combined anti-OX40/ anti-CTLA-4 immunotherapy augmented anti-tumor

\footnotetext{
2Earle A. Chiles Research Institute, Providence Cancer Center, Portland, OR, USA

Full list of author information is available at the end of the article
}

CD8 $\mathrm{T}$ cell function, while limiting Th2 polarization in CD4 cells and improving overall survival.

\section{Authors' details}

${ }^{1}$ Earle A. Chiles Research Institute/Providence Health and Services, Portland, OR, USA. ²Earle A. Chiles Research Institute, Providence Cancer Center, Portland, OR, USA.

Published: 4 November 2015

doi:10.1186/2051-1426-3-S2-P360

Cite this article as: Linch et al:: Combination OX40 agonism/CTLA-4 blockade with HER2 vaccination reverses T cell anergy and promotes survival in tumor-bearing mice. Journal for ImmunoTherapy of Cancer 2015 3(Suppl 2):P360.

\section{Submit your next manuscript to BioMed Central and take full advantage of: \\ - Convenient online submission \\ - Thorough peer review \\ - No space constraints or color figure charges \\ - Immediate publication on acceptance \\ - Inclusion in PubMed, CAS, Scopus and Google Scholar \\ - Research which is freely available for redistribution

